DOI: 10.24833 / 0869-0049-2018-4-54-63

\author{
Dmitry K. LABIN \\ Moscow State Institute of International Relations (University) MFA Russia \\ 76, pr. Vernadskogo, Moscow, Russian Federation, 119454 \\ d.labin@inno.mgimo.ru \\ ORCID: 0000-0002-1493-4221

\section{Renata R. MURATOVA} \\ Moscow State Institute of International Relations (University) MFA Russia \\ 76, pr. Vernadskogo, Moscow, Russian Federation, 119454 \\ renata.muratova@hotmail.com \\ ORCID: 0000-0001-9441-3823
}

\title{
NEW APPROACHES TO THE BALANCE BETWEEN INVESTOR PROTECTION AND THE RIGHT TO REGULATE WITHIN MEGA-REGIONAL AGREEMENTS
}

INTRODUCTION. In 2015 UNCTAD elaborated a roadmap for international investment agreements reform, aimed at bringing the terms of such agreements in line with modern sustainable development imperatives. For a long time the question of the balance between investor protection in the territory of the host state and the right of this state to regulate within international investment and trade agreements has caused controversy among international law scholars. In particular, very often international agreements endow foreign investors with greater rights thereby limiting sovereign rights of the host state. The present article provides a comparative analysis of the investment protection and promotion provisions under the Comprehensive Economic and Trade Agreement (CETA) and the Comprehensive and Progressive Agreement for Trans-Pacific Partnership (CPTPP or TPP-11). Also, for the first time among Russian scholars, the authors give an analysis of the changes that occurred during the signature of the CPTPP Agreement on March 8, 2018 after the US withdrawal at the beginning of 2017.

MATERIALS AND METHODS. The research in the article is based on the provisions of the CPTPP and CETA that regulate foreign investments as well as the works of Russian and foreign international investment law scholars. It is necessary to mention the significant role of the World Investment Reports, published by UNCTAD in 2016 and 2017, in making a comparison of provisions dedicated to investment protection and the right to regulate, contained in different international investment agreements and bilateral investment treaties.

RESEARCH RESULTS. In-depth analysis of CPTPP and CETA provisions that regulate foreign investments showed that these agreements contain unique and innovative provisions that could rarely be found in contemporary international investment agreements. These provisions not only clarify the foreign investor rights when carrying out activities on the territory of the host state, giving more detailed description of the states obligations and the guarantees provided, but also specify rules for the investorstate disputes settlement.

DISCUSSION AND CONCLUSIONS. Both megaregional agreements, analyzed in the present article, contain extensive chapters devoted to achievement of maximum transparency in dispute settlement, while 
CETA introduces its own Investment Court System which includes a permanent appellate body. At the same time, the CPTPP Agreement for the first time, compared with already existent investment agreements, carves out a specific product - tobacco - from protection when settling investor-state disputes. Although neither CETA, nor CPTPP have yet been ratified by the parties, it is important to consider how these provisions on investment regulation would shape future international investment agreements and bilateral investment treaties.

KEYWORDS: investments, Comprehensive Eco- nomic and Trade Agreement (CETA), Comprehensive and Progressive Agreement for Trans-Pacific Partnership (CPTPP), investment protection, right to regulate, reform of the investor-state dispute settlement, Investment Court System

FOR CITATION: Labin D.K., Muratova R.R. New Approaches to the Balance between Investor Protection and the Right to Regulate within Mega-regional Agreements. - Moscow Journal of International Law. 2018. No. 4. P. 54-63.

DOI: $10.24833 / 0869-0049-2018-4-54-63$

DOI: 10.24833 / 0869-0049-2018-4-54-63

\section{Дмитрий Константинович ЛАБИН}

Московский государственный институт международных отношений (Университет) МИД России Проспект Вернадского, д. 76, Москва, 119454, Российская Федерация

d.labin@inno.mgimo.ru

ORCID: 0000-0002-1493-4221

\section{Рената Равилевна МУРАТОВА}

Московский государственный институт международных отношений (Университет) МИД России Проспект Вернадского, д. 76, Москва, 119454, Российская Федерация

renata.muratova@hotmail.com

ORCID: 0000-0001-9441-3823

\section{НОВЫЕ ПОДХОДЫ В СООТНОШЕНИИ ПРАВА НА ЗАЩИТУ ИНВЕСТИЦИЙ И ПРАВА НА РЕГУЛИРОВАНИЕ В РАМКАХ МЕГАРЕГИОНАЛЬНЫХ СОГЛАШЕНИЙ}

ВВЕДЕНИЕ. Еще в 2015 г. ЮНКТАД предложила дорожную карту реформы международных инвестиционных согламений, нацеленную на приведение режима таких договоров в соответствие с сегоднятними императивами устойчивого развития. На протяжении длительного времени именно вопрос о соотнотении прав иностранного инвестора на территории принимающего государства и права этой страны на регулирование в рамках международных ин- вестиционных и торговых соглачений вызывал полемику среди юристов-международников. В частности, нередко междннародные договоры наделяли иностранного инвестора большими правами, ограничивая тем самым суверенные права принимающего государства. В настоящей статье приведен сравнительный анализ положений по защите и поотрению инвестииий в рамках двух соглашений нового поколения: Согламения о всеобъемлющей зоне свободной 
торговли между Канадой и Европейским союзом (СЕТА) и Всеобъемлюшего и прогрессивного соглашения для Транстихоокеанского партнерства (ВПТТП или ТТП-11). Впервые в отечественной доктрине рассмотрень изменения, происшедшие при подписании странами-партнерами Соглашения о ТТП-11 8 марта 20182. без участия США.

МАТЕРИАЛЫ И МЕТОДЫ. Настоящзее исследование основано на анализе отдельных положений глав Соглашения о ТТП-11 и СЕТА, регулируюших иностранные инвестиции. Кроме того, в статье были рассмотрень труды отечественных и зарубежных исследователей в области международного инвестииионного права. Важную роль при сравнении положений по зашите инвестиций и права на регулирование сыграли доклады о мировых инвестиииях, подготовленные ЮНКТАД в 2016-2017 22.

РЕЗУЛЬТАТЫ ИССЛЕДОВАНИЯ. Углубленный анализ глав Соглашения о ТТП-11 и СЕТА, посвященных регулированию инвестиций, позволил определить, что данные договоры содержат в себе новые подходы к регулированию инвестиций, которье практически не встречаются в действуюших двусторонних инвестиционных соглашениях. Это касается не только уточнения прав иностранного инвестора при осуществлении деятельности на территории принимающей страны, но и улучшенной модели суверенного права государства на регулирование. Кроме того, были рассмотрень детально оформленные обязательства государств и предоставляемые ими гарантии, а также порядок урегулирования споров между инвестором и государством.

ОБСУЖДЕНИЕ И ВЫВОДЫ. Рассматри- ваемые в статье мегарегиональные соглашения содержат достаточно объемную часть, посвященную достижению максимальной прозрачности при урегулировании споров, причем СЕТА идет дальше и вводит собственную систему инвестииионных судов, в рамках которой действует постоянныц апелляицонный трибунал. В то же время Соглашение о ТТП-11 впервые среди уже существуюших инвестиционных договоров исключает договорную защиту инвесторов не только в чувствительных секторах сферь услуг, но и в производственном секторе национальной экономики - табачной отрасли. Хотя ни одно из рассматриваемых в настоящей статье соглашений пока еще не ратифииировано сторонами, важно определить, каким образом положения по регулированию инвестиций могут повлиять на будущий облик международных инвестиционных соглашений и двусторонних инвестиционных договоров.

КЛЮЧЕВЫЕ СЛОВА: инвестииии, Всеобъемлющее экономическое и торговое соглашение (СЕТА), Всеобъемлющее и прогрессивное соглашение для Транстихоокеанского партнерства (ВПТТП или ТПП-11), защита инвестиций, право на регулирование, реборма механизма международного урегулирования споров между инвестором и государством, система инвестииционных судов

ДЛЯ ЦИТИРОВАНИЯ: Лабин Д.К., Муратова Р.Р. 2018. Новые подходы в соотношении права на защиту инвестиций и права на регулирование в рамках мегарегиональных соглашений. - Московский журнал международного права. № 4. C. 54-63.

DOI: 10.24833/0869-0049-2018-4-54-63
$\mathrm{T}$ he balance between the right to protect private foreign investments and the right of host countries to regulate foreign investments within their own jurisdiction is the key issue when searching for a proper international legal mechanism to overview cross-border flows of capital in terms of globalization of the world economy either in the treaty practice of states or in academic discussions in this area. The criticism that has developed here concerns essentially only those provisions of international in- vestment treaties that limit the freedom of the contracting states to choose sovereign measures to regulate the economic activities of foreigners within their own territory. Their opponents, on the contrary, note that international conventional norms protect only covered investors [Gaukrodger 2017:40].

According to the 2017 UNCTAD World Investment Report, in 2016 there have been concluded 37 new international investment agreements: 30 bilateral investment treaties (BITs) and 7 agreements 
containing provisions on investment regulation ${ }^{1}$. Among them there have been signed 2 mega-regional agreements - the Comprehensive Economic and Trade Agreement (CETA) between Canada and the European Union and the Trans-Pacific Partnership Agreement (TPP) [Lebedeva 2017:54-69].

However, on January 22, 2017 newly elected US President D. Trump signed an executive order on the US withdrawal from the TPP Agreement, which called into question the future of the partnership [Molchakov, Yakunin 2018:56-57]. It is necessary to note that the TPP Agreement does not provide for the termination of the agreement following the withdrawal of the party. But the access to the market of the largest importer of goods and services, which is the USA, has been one of the main objectives of cooperation for the partner states. At the same time, according to some researches, the TPP Agreement was part of the US "divide and conquer" global strategy, which included the need for the US to participate in negotiations that could weaken some trading partners in order to "secure the outcomes it prefers" [Benvenisti 2015:23]. In particular, this could become possible at the regional level, rather than within global trade institutions such as the WTO [Alvarez 2016:49].

Yet, despite the withdrawal of one of the main parties, on March 8, 2018 in Santiago, Chile the remaining 11 countries signed a new agreement that became a milestone in the development of their relations within the TPP - The Comprehensive and Progressive Agreement for the Trans-Pacific Partnership, CPTPP or TPP- $11^{2}$. It should be mentioned that the text of the new agreement incorporates almost completely the text of the old TPP Agreement (it is included in the CPTPP Agreement by reference), aside from 22 suspended provisions that mostly concern intellectual property rights, cross border trade in services and investments. According to some experts, it was these provisions that were promoted by the USA at the stage of negotiation of the initial text of the TPP Agreement [Flynn et al. 2013: 105-202].
Another mega-regional agreement - CETA - was signed by the contracting parties on October 30, $2016^{3}$. It will replace eight already existing bilateral investment treaties between Canada and each individual EU member state. CETA became the first agreement in the treaty history of the EU that contains provisions both for the investment protection and a dispute settlement mechanism to enforce this protection [Puccio, Harte 2017:34]. It should be mentioned that Canada also is a partner state to the CPTPP.

Despite the fact that both CPTPP and CETA have yet to be ratified by the partner states (in the case of CETA - each EU state separately) before they enter into force, the Art. 30.7(3) of CETA provides for the possibility of provisional application prior to ratification by all EU member states. This became possible after CETA was ratified by the European Parliament on February 15, 2017 on the one side, and Canada on May 16, 2017 on the other. Following the joint statement during the G20 summit (July 2017) both parties to the Agreement decided to apply CETA provisionally starting from September 21,20174. In its decision as of October 27, 2016, the Council of the European Union clearly defined the CETA stipulations that could be provisionally applied ${ }^{5}$. It is important to take into consideration that the provisional application of CETA refers only to those provisions that are within the competence of the European Parliament, for example, by now, customs duties were eliminated for $98 \%$ of goods constituting mutual trade between the EU and Canada which means it will allow the EU to save 590 million euros per year [Chuvakhina 2018:51-58]. In turn, the provisions relating to the investment sphere of cooperation, for example the Investment Court System (ICS), that will be discussed later, will be applied only after the final ratification of the Agreement by each EU member state is made. To date the parliaments of some EU states including Denmark, Latvia, Spain, Croatia and Portugal have already ratified the CETA.

\footnotetext{
1 World Investment Report 2017: Investment and the Digital Economy. P. 111. URL: http://unctad.org/en/Publications Library/wir2017_en.pdf (accessed date: 17.08.2018).

2 Government of Canada: Official text of CPTPP. URL: http://international.gc.ca/trade-commerce/trade-agreementsaccords-commerciaux/agr-acc/cptpp-ptpgp/text-texte/index.aspx?lang=eng (accessed date: 17.03.2018).

3 European Commission: CETA chapter by chapter. URL: http://ec.europa.eu/trade/policy/in-focus/ceta/ceta-chapter-bychapter/ (accessed date: 15.08.2018).

4 Statement by Mr Jean-Claude Juncker, President of the European Commission and Mr Justin Trudeau, Prime Minister of Canada "EU and Canada agree to set a date for the provisional application of the Comprehensive Economic and Trade". URL: http://europa.eu/rapid/press-release_STATEMENT-17-1959_en.htm (accessed date: 23.08.2018).

5 Council Decision on the provisional application of the Comprehensive Economic and Trade Agreement (CETA) between Canada, of the one part, and the European Union and its Member States, of the other part. URL: http://data.consilium. europa.eu/doc/document/ST-10974-2016-INIT/en/pdf (accessed date: 23.08.2018).
} 
Provisions ensuring an appropriate balance between the rights of foreign investors and host countries are grouped into separate sections of each of the international legal documents (CETA and CPTPP in Chapters 8 and 9, respectively). In general, both agreements provide for a standard set of obligations for Member States to protect the rights of the foreign investor and his investments, including the most-favored-nation treatment, national treatment, protection against unlawful expropriation, and minimum standard of treatment.

As it was previously mentioned, when the text of the CPTPP was agreed upon by the partner states, some of the provisions of the investment chapter were suspended. However, it does not significantly change the basis for regulating investment relations between partner states. In particular, the partner states have suspended the term "investment agreement", often used when concluding investment agreements in primary industries (oil, mining, etc.) and the "investment authorization" from Art. $9^{6}$.

It is important to keep in mind that the suspention of an "investment agreement" out of the protection of the investor-state dispute setlement mechanism does not mean that any foreign investor is deprived of protection under Chapter 9. Article 9.1 contains a rather broad definition of the "investment" clarifying all types of investments that can be subject to arbitration. Thus, if a foreign investor has an agreement with the host state, and the subject of this agreement is an "investment" in accordance with Art. 9.1, then the foreign investor has the right to initiate the "investment dispute" (Art. 9.19) based on the violation by the host state of the foreign investor protection principles set out in Section A of the investment chapter of the CPTPP (minimum standard, principle of non-discrimination, expropriation, etc.).

The suspension of the term "investment authorization" should also be read in conjunction with the rest of the Chapter 9, namely the definition of "investment", which protects "licenses, authorisations, permits and similar rights conferred pursuant to the Party's law". Accordingly, in order to challenge the actions of the host state, the investor in each case must prove that his license, authorisation or permit falls under the definition of "investment" in order to initiate further an "investment dispute".
Difficulties concerning the balance between the rights of a foreign investor and host state are undoubtedly related to differences in final goals: more often the interests of the former are aimed at obtaining maximum economic profit, while the interests of the latter also include the need to protect public interests, the environment, etc. Accordingly, this leads to different "expectations" of the parties to the investment agreement. In particular, it is about the concept of investor's "legitimate expectations", originating from the standard of fair and equitable treatment provided by a host state [Rachkov 2014:196-220]. This concept allows foreign investors to file a claim with the state in international investment arbitration in cases where the state did not meet the investor's legitimate expectations. The contracting parties to CETA agreed on important provisions that ensure their right to regulate in order to achieve goals related to the protection of public health, safety, the environment, public morals, social and consumer rights, as well as the protection and promotion of cultural diversity (Art. 8.9.1). In this regard, in addition to Art. 8.9.1, Art. 8.9.2 of the CETA clarifies that any action, as well as the omission of the host state (including changing its national legislation) that did not meet the expectations of the foreign investor, will not constitute a violation by the host state of a fair and equitable standard, even if it has led to damage to the investment.

In turn, the provisions of Chapter 9 of the CPTPP Agreement provide greater certainity within the definitions of "non-discrimination" and "minimum standard of treatment". For example, the right of a contracting state to take certain measures aimed at protecting public welfare is allowed as an exemption, even if they are inconsistent with an investor's expectations. Now there is no breach of the obligations.

Along with the increase in the number of concluded investment agreements, the number of investor-state disputes under these agreements is growing. According to the above-mentioned annual investment report of UNCTAD, in 2016, there were 62 new disputes initiated, which increased the number of already known cases to $767^{7}$.

Representing models of the "new era" investment agreements, both projects offer to the interested for-

\footnotetext{
6 TPP11: Unpacking the suspended provisions. - Asian Trade Center - Policy Brief. 2017. No. 17-11. URL: https://static1. squarespace.com/static/5393d501e4b0643446abd228/t/5a0a27b1f9619a1bb0564c62/1510614967962/Policy+Brief+1711+TPP11+Suspensions.pdf (accessed date: 08.08.2018).

7 World Investment Report 2017: Investment and the Digital Economy. P. 12. URL: http://unctad.org/en/Publications Library/wir2017_en.pdf (accessed date: 17.08.2018).
} 
eign investors an investor-state dispute settlement mechanism. Although the mechanisms themselves differ, the provisions establishing these mechanisms are among the most controversial in the opinion of some international lawyers [Hufbauer 2016:109119].

According to international law rules, as well as widely recognized doctrine and practice, an investment dispute between foreign investor and host state can be subject to the home State espousal via diplomatic processes only when all domestic remedies (lex situs) have been exhausted in accordance with the legislation of the host state [Labin 2008:255]. However, the contracting states by agreement give foreign investors the right, at their own discretion, to bring a claim to international arbitration specified in the provisions of the agreement. This right, of course, gives a foreign investor greater protection. However, at the same time, it should be considered that the investor-state dispute has a private law nature, and the state is subject to international law. Therefore, the right of the state to regulate is restricted. Accordingly, there is a point of view that international investment agreements create rights for investors, but duties and responsibilities for states [Rachkov 2016:118-136].

In addition, ad hoc investment arbitrations provided for in many bilateral and international investment agreements are often distinguished by holding closed hearings, the parties to the dispute are the one's appointing the arbitrators, and agreements do not provide for certain qualifications or competencies to discharge the function. Thus, the problem of inconsistency and unpredictability of arbitration practice arises [Gudkov 2015:10].

In accordance with the Art. 9.19.4 of the CPTPP investors are provided with an opportunity to submit a claim in national courts on the territory of the host state, or to submit a claim to the International Center for Settlement of Investment Disputes (ICSID) under its Rules of Procedure for Arbitration Proceedings or Additional Facility Rules or to an ad hoc arbitration under UNCITRAL Arbitration Rules. Thus, a foreign investor is free from the need to exhaust domestic means of legal protection. At the same time, the possibility of a parallel consideration of a dispute on one factual basis in various arbitrations is also excluded, which aims at preventing unfair attempts of abuse by a foreign investor to choose the arbitration of another body that is most beneficial for him (the so-called "forum shopping") [Stephenson, Caroll 2016:200-215]. These provisions are aimed at avoiding payment of double compensation, as well as making contradictory decisions on the same dispute.

Unlike traditional mechanisms for settling investment disputes provided for in this category of international agreements, CETA offers a completely new approach - the creation of the Investment Court System. For the first time, the idea of establishing a permanent jurisdictional body was expressed during the negotiations between the EU and the United States on the Transatlantic Trade and Investment Partnership (TTIP), which already contained a similar arbitration clause. Caused by public protests, as well as after public consultations, the European Parliament, in its resolution as of July $8,2015^{8}$, demanded that the existing mechanism for resolving investment disputes be replaced by a permanent court, including an appelate body ${ }^{9}$. In general, among citizens of European Union states, investment arbitration is often associated with an unjust and poorly controlled method of settling disputes ${ }^{10}$. In this regard, Belgium signed the CETA, provided that the EU Court of Jus-

\footnotetext{
8 European Parliament Resolution 2014/2228(INI) of 8 July 2015 containing the European Parliament's recommendations to the European Commission on the negotiations for the Transatlantic Trade and Investment Partnership (TTIP). URL: http://www.europarl.europa.eu/sides/getDoc.do?pubRef=-//EP//TEXT+TA+P8-TA-2015-0252+0+DOC+XML+V0//EN (accessed date: 17.08.2018).

9 On November 16, 2015 the European Commission proposed draft provisions for a permanent international investment court (IIC) for the TTIP and other agreements containing provisions on promotion and protection of foreign investments. During the negotiations the EU representative underlined that the IIC mechanism would facilitate the implementation of the right to regulate by contracting states. See Blog by Cecilia Malmström on Proposing an Investment Court System (2015). URL: https://ec.europa.eu/commission/commissioners/2014-2019/malmstrom/blog/investments-ttip-andbeyond-towards-international-investment-court_en (accessed date: 17.08.2018). The Commission also announced the start of negotiations on the draft articles for the IIC together with all interested states. In November 2015 a draft text of the relevant provisions on the court and appellate body was prepared to be included in the TTIP investment chapter. In December 2015 the EU and Vietnam signed a FTA that contains provisions on the proposed international jurisdictional bodies.

${ }^{10}$ Ispolinov A.S. 2015. Evropeiskii Soyuz i reforma investarbitrazha: vynuzhdennaya zhertva ili dymovaya zavesa? [The European Union and the Investment Arbitration Reform: a forced victim or a smoke screen?]. - Zakon. November 11, 2015. URL: https://zakon.ru/blog/2015/11/17/evropejskij_soyuz_i_reforma_investarbitrazha_vynuzhdennaya_zhertva_ ili_dymovaya_zavesa (accessed date: 17.08.2018).
} 
tice considers the issue of compliance of the CETA provisions with European Union law ${ }^{11}$.

The entire Investment Court System was included in CETA, consisting of the Tribunal (Art. 8.27) and the Appellate Tribunal (Art. 8.28). In addition, unlike the traditional approach to resolving investment disputes, the Tribunal will consist of 15 members appointed by the parties to an international treaty - the European Union and Canada respectively, and not the investor and the host state, as provided for by the vast majority of modern BITs. The hearings themselves will be held with the participation of three judges elected on a rotation basis. Incidentally, the rotation concept for electing arbitrators is also enshrined in the CPTTP text.

This measure is important within the framework of reforming the existing system of investment disputes settlement. As it turned out, more than a half of the awards of the investment arbitrations were adopted by a narrow group of 15 arbitrators [Ispolinov 2015:80-96], appointed by the parties from one case to another. It may be mentioned that arbitrators are paid with high fees. Many researchers cite as an example the cases Yukos shareholders v. Russia [Ispolinov 2015:80-96], after which the arbitrators' fee was settled at 1.5 to 2 million euros [Rachkov 2016:118-136].

Additionally, like some other states which signed the new Agreement CPTTP New Zealand has concluded side letters limiting the possibility of using the investor-state dispute settlement mechanism ${ }^{12}$. Supplementary agreements with Australia and Peru completely curbed this possibility. Previously, as far back as 2016, within the framework of the TTP both Australia and New Zealand established an exception to the mechanism for settling investment disputes. For these countries, the settlement of investment disputes is possible only in national courts of the host state (Chapter 9, Section B of the CPTPP). This provision demonstrates the mutual confidence between Australia and New Zealand concerning national legislative and judicial systems due to their similarity and development in terms of providing protection to a foreign investor [Nottage 2016:1-36].

At the same time, additional side letters with Brunei, Malaysia and Vietnam provide for the following procedure. The foreign investor, first of all, will have to try to settle the controversial issue with the government of the host state through consultations and negotiations (which, among other things, include good offices, mediation and conciliation). After 6 months, in case of failure of consulting or conciliation measures, a foreign investor may request the consent of the host state to consider the dispute through the mechanism provided by the CPTPP. If the government refuses to give its consent, the national state of the investor may request consultations at the interstate level.

The procedural part of submitting a claim by a foreign investor to arbitration is also described in great detail within the framework of both agreements. At the first stage, both CETA and CPTPP provide for the parties to hold consultations. According to Art. 8.19 of CETA, consultations shall be held within 60 days of the submission of the request for consultations, unless the parties in dispute have agreed on a longer period of time. The CPTPP provides for a period of 6 months from the date of receipt by the counterpart of a written request for consultations.

In accordance with Art. 9.22 of the CPTPP, the tribunal comprises 3 arbitrators: each party to the dispute chooses one arbitrator, and the third, presiding arbitrator, is elected by mutual agreement of the parties. If within 75 days from the date the claim was submitted the tribunal has not been constitued, the Secretary-General of the ICSID shall appoint arbitrators at his or her own discretion.

If one of the arbitrators fails to comply with strict ethic rules (Art. 8.30 CETA), he/she will be replaced, but this decision will be made by an independent party, namely the President of the International Court of Justice. Such rules can make a contribution in the process of taking impartial decisions by arbitrators, as well as help reduce the likelihood of erroneous judgments.

Within the framework of the system provided by CETA, an important component is the possibility of referring the case to an appellate body. The very existence of such a body is an innovation within the framework of the international investment disputes settlement. The decision of investment arbitration has always been implied to be final and not subject to appeal. In the framework of the ICSID, in accordance

\footnotetext{
11 Belgium's request for an opinion on the compatibility of the Investment Court System (ICS) with the European Treaties to the Court of Justice of the European Union. URL: https://diplomatie.belgium.be/sites/default/files/downloads/ceta summary.pdf (accessed date: 17.08.2018).

12 Parker H.D. New Zealand Signs Side Letters Curbing Investor-state Dispute Settlement. - The official website of the New Zealand Government. March 9, 2018. URL: https://www.beehive.govt.nz/release/new-zealand-signs-side-letters-curbinginvestor-state-dispute-settlement (accessed date: 03.09.2018).
} 
with the existing procedure stipulated by the Washington Convention on the Settlement of Investment Disputes Between States and Nationals of Other States, 1965, the disputing parties have an opportunity to request annulment of the award, but such a procedure does not imply consideration on the merits of the case or the adoption of a new award, which is the main purpose of the appellate body [Ispolinov 2015:80-96].

The lack of transparency in the investor-state dispute settlement, in particular, closed dispute settlement sessions, which also corresponds the interests of a foreign investor, have caused great controversy over the years [Van Harten 2016:103-130]. Many international investment agreements and BITs stipulate that hearings on a dispute, as well as all details of a dispute, can be kept in complete confidentiality if the disputing parties wish so, even in cases where the dispute affects public interests ${ }^{13}$. For example, Art. 25(4) of the UNCITRAL Arbitration Rules provides for holding a court session "in camera unless the parties agree otherwise"14. The CETA and CPTPP provide for full transparency throughout the entire dispute settlement period. According to the provisions of both agreements, all documents (written submissions of the disputing parties, the award of the arbitration) will be kept in the public domain. The exception composes protected information, as well as confidential business information protected from the disclosure under a party's legislation. All conditions of confidentiality of information are clearly stated in the relevant paragraphs of the agreements under consideration. All hearings will be open to the public, and third parties interested in the dispute will also be able to make their written submissions (amicus curiae $)^{15}$.

It is important to outline that Chapter 9 (Art. 23.7) of the CPTPP Agreement explicitly states that the burden of prooving all elements of its claims in the process of settling a dispute lies precisely on the investor, and not on the respondent state.

The Art. 29.5 of the CPTPP carves out tobacco from the provisions of the dispute settlement be- tween the investor and the host state. Usually, in the practice of concluding international investment agreements, exceptions concerned broader areas of trade in goods and services. Hufbauer discusses that such an exception within the framework of the CPTPP can set a precedent for creating regulations on the exclusion of alcoholic products, corn syrup and other goods that may harm health or the environment [Hufbauer 2016:109-119]. One of the reasons for introducing such an exception into the text of the CPTPP could possibly become a lawsuit filed by Australia's Philip Morris Asia tobacco company in 2011 under the Australia-Hong Kong BIT, regarding the plain packaging law introduced by Australia in 2011, about restrictions on brand image (it could be placed only in a certain place on the packaging) and the introduction of a unified type of cigarette packs. Unified packaging was understood as matte brown packaging with no logos, trademarks and colors on it. On December 17, 2015, the Tribunal hearing the case resolved the dispute in favor of Australia, ruling that it is precluded from exercising jurisdiction over the dispute ${ }^{16}$.

It should be outlined that this dispute also influenced the development of some provisions of CETA. In particular, Art. 8.18.3 prohibits consideration of a case when "investment has been made through fraudulent misrepresentation, concealment, corruption, or conduct amounting to an abuse of process"17. Thus, CETA prevents fraudulent or misleading claims by foreign investors against the host state. In addition, under Arts. 8.32 and 8.33, there is an accelerated procedure for filing an objection that a claim resulted being without legal merit, which may take only a few weeks. These provisions are broader in application than in any other comparable agreements, with the exception of agreements with EU participation (for example, the EU - Vietnam FTA Agreement).

In general, some of the provisions for the protection and promotion of investments under the CETA and the CPTPP Agreement do more precisely regulate the rights of a foreign investor and the host

\footnotetext{
13 Reform of Investor-State Dispute Settlement: in search of a roadmap. UNCTAD IIA Issues Note. 2013. No. 2. URL: https:// unctad.org/en/PublicationsLibrary/webdiaepcb2013d4_en.pdf (accessed date: 08.08.2018).

${ }_{14}$ UNCITRAL Arbitration Rules. General Assembly Resolution 31/98. URL: http://www.uncitral.org/pdf/english/texts/ arbitration/arb-rules/arb-rules.pdf (accessed date: 08.08.2018).

15 See Art. 8.36 "Transparency of proceedings" (CETA), Art. 9.24 "Transparency of Arbitral Proceedings" (CPTPP Agreement). 16 Philip Morris Asia Ltd. v. The Commonwealth of Australia. PCA Case No. 2012-12 (Award on Jurisdiction and Admissibility) dated December 17, 2015. URL: https://www.italaw.com/sites/default/files/case-documents/italaw7303_0.pdf (accessed date: 25.08 .2018 ).

17 Shaposhnikova O.S. The Philip Morris Case and the Right to Regulate (Legislate). - International Law Square. February 5, 2016. URL: https://ilsquare.org/2016/02/05/the-philip-morris-case-and-the-right-to-regulate-legislate/ (accessed date: 19.08.2018).
} 
state. Undoubtedly, these provisions can be considered as a prototype of the new investment rules, which can subsequently be incorporated into international investment agreements and new-generation BITs.

With the general commitment of both agreements to assist states in their right to regulate, it must be recognized that the CETA goes a little further than the CPTPP, giving the state greater rights under the investor-state dispute settlement mechanism. However, after the US's withdrawal from the TTP Agreement, the remaining partner states, in our opinion, have significantly expanded the area of their right to regulate within the new CPTPP Agreement.

At the same time, there is a necessary detail worth mentioning: CETA provides that access to the Investment Court System can be obtained not only by national companies of the EU and Canada, but also by foreign companies operating in their territory. In particular, a large number of US companies carry out their activities in Canada. Keeping in mind that negotiations between the EU and the United States to establish the TTIP in 2017 were suspended, there is a high probability that US companies operating in Canada and investing in EU countries, regardless of the location of their head office, will be able to file suit against the EU as a party of CETA, respectively. According to some analysts, this will lead to the vulnerability of European business, especially small and medium-sized, and also contradicts the fundamental socially oriented development model of EU countries due to the likely priority of corporate interests

\section{References}

1. Alvarez Jose E. Is the Trans-Pacific Partnership's Investment Chapter the New "Gold Standard"? - Institute for International Law and Justice Working Paper. 2016. No. 3. 49 p. URL: https://wp.nyu.edu/megareg/wp-content/ uploads/sites/3134/2016/03/Alvarez_IILJ-MegaReg_2016-3.pdf (accessed date: 09.05.2018).

2. Benvenisti E. Democracy Captured: The Mega-Regional Agreements and the Future of Global Public Law. - GlobalTrust Working Paper Series. 2015. No. 8. 23 p. DOI: http://dx.doi.org/10.2139/ssrn.2646882

3. Chuvakhina L.G. CETA: novyi etap v razvitii otnoshenii Kanady i Evropeiskogo Soyuza [CETA: A New Stage in the Development of Relations between Canada and the European Union]. - Vestnik Astrakhanskogo gosudarstvennogo tekhnicheskogo universiteta. Seriya. Ekonomika. 2018. No. 1. P. 51-58. (In Russ.). DOI:10.24143/20735537-2018-1-51-58

4. Flynn S.M. [et al.]. The U.S. Proposal for an Intellectual Property Chapter in the Trans-Pacific Partnership Agreement. - American University International Law Review. 2013. Vol. 28. No. 1. P. 105-202. DOI: http://dx.doi. over the norms of national legislation [Chuvakhina 2018:51-58].

However, after analyzing the chapters of CETA and СРТPP on investment regulation, we emphesise that both Agreements attempt to find a way to find a balance between the public interests of states and the private interests of investors, giving greater freedom to foreign investors, but at the same time, protecting the inalienable right of the state to regulate in order to protect the public interest. Certainly, to a greater extent, this is demonstrated by the attention of the contracting parties to CETA and CPTPP to a clearer interpretation of the principle of non-discrimination, as well as the fair and equitable treatment in general.

The issue of using investment arbitration in dispute settlement between a foreign investor and a host state, as noted, has repeatedly provoked controversy among international lawyers and great public discontent. In this article, both the advantages and disadvantages of the proposed CETA and CPTTP systems for dispute settlement were noted, but the authors come to the conclusion that by making the mechanisms more transparent, clarifying definitions, and also generally striving to more clearly mark the state's right to regulate, these mechanisms will be able to show themselves in the best light.

Both CETA and the CPTPP Agreement are still to be ratified, and only after successfully completing this procedure will it be possible to evaluate the implementation of the above-mentioned innovative provisions for the protection and promotion of investment in practice.

org/10.2139/ssrn.2185402

5. Gaukrodger D. The Balance between Investor Protection and the Right to Regulate in Investment Treaties: a scoping papers. - OECD Working Papers on International Investment. 2017. No. 2. 40 p. DOI: http://dx.doi. org/10.2139/ssrn.3147346

6. Gudkov I. Soglashenie o Transatlanticheskom torgovoinvestitsionnom partnerstve: ot zashchity ekonomicheskikh interesov investorov k zashchite suverennykh interesov prinimayushchikh storon? [Transatlantic Trade and Investment Partnership: from protecting the economic interests of investors to protecting the sovereign interests of the host parties?]. - Vsya Evropa. 2015. No. 10 (103). (In Russ.) URL: http://alleuropalux. org/?p=12248 (accessed date: 05.06.2018).

7. Hufbauer G.C. Investor-State Dispute Settlement. - Assessing the Trans-Pacific Partnership. Vol. 1: Market Access and Sectoral Issues. Peterson Institute for International Economics. 2016. P. 109-119. URL: https://piie.com/ system/files/documents/piieb16-1.pdf (accessed date: 15.08.2018).

8. Ispolinov A.S. Kuda idet sovremennyi investitsionnyi arbitrazh? [Where does the Modern Investment Arbitra- 
tion go?]. - Rossiiskii yuridicheskii zhurnal. 2015. No. 3 (102). P. 80-96. (In Russ.)

9. Labin D.K. Mezhdunarodnoe pravo po zashchite i pooshchreniyu inostrannykh investitsii [International Law on Protection and Encouraging of Foreign Investments]. Moscow: Walters Kluwer Publ. 2008. 315 p. (In Russ.)

10. Lebedeva L.F. Transkontinental'nye partnerstva na pereput'e: faktory, riski, posledstviya [Transcontinental Partnerships at the Crossroads: factors, risks, consequences]. - Outlines of Global Transformations: politics, economics, law. 2017. Vol. 10. Issue 4. P. 54-69. (In Russ.). DOI: https://doi.org/10.23932/2542-0240-2017-10-454-69

11. Molchakov N.Yu., Yakunin V.I. Fenomen Trampa i amerikanskaya sistema razdeleniya vlastei [The Phenomenon of Trump and the American System of Separation of Powers]. - MGIMO Review of International Relations. 2018. No. 1. P. 42-62. (In Russ.) DOI: 10.24833/20718160-2018-1-58-42-62

12. Nottage L. The TPP Investment Chapter and Investorstate Arbitration in Asia and Oceania: assessing prospects for ratification. - Melbourne Journal of International Law. 2016. Vol. 17. Issue 2. P. 1-36. DOI: http://dx.doi. org/10.2139/ssrn.2767996

13. Puccio L., Harte R. From Arbitration to the Investment Court System (ICS): The evolution of CETA rules. 2017.
34 p. URL: http://www.europarl.europa.eu/RegData/ etudes/IDAN/2017/607251/EPRS_IDA(2017)607251_ EN.pdf (accessed date: 05.06.2018).

14. Rachkov I.V. Kontseptsiya "zakonnykh ozhidanii inostrannogo investora" v praktike mezhdunarodnykh investitsionnykh arbitrazhei [Concept of "Legitimate Expectations" of Foreign Investors in the International Investment Arbitration Practice]. - Moscow Journal of International Law. 2014. No. 1 (93). P. 196-220. (In Russ.)

15. Rachkov I.V. Reforma mezhdunarodno-pravovogo uregulirovaniya sporov mezhdu inostrannymi investorami i gosudarstvami [Reforming International Resolution of Disputes between Foreign Investors and Host States]. Mezhdunarodnoe pravosudie. 2016. No. 3 (19). P. 118136. (In Russ.). DOI: 10.21128/2226-2059-2016-3-118136

16. Stephenson A., Carroll L. 2016. The Trans-Pacific Partnership. - The Investment Treaty Arbitration Review. Ed. by B. Legum. London: Law Business Research Ltd. 2016. P. 200-213.

17. Van Harten G. Reforming the System of International Investment Dispute Settlement. - Alternative Visions in the International Law on Foreign Investment: Essays in Honor of Muthucumaraswamy Sornarajah. Ed. by C.L. Lim. Cambridge: Cambridge University Press. 2016. P. 103-130.

\section{About the Authors}

\section{Dmitry K. Labin,}

Doctor of Juridical Sciences, Professor at the Department of Intenrational Law, Head of the Department of Public Law, Moscow State Institute of International Relations (University) MFA Russia

76, pr. Vernadskogo, Moscow, Russian Federation, 119454

d.labin@inno.mgimo.ru

ORCID: 0000-0002-1493-4221

\section{Renata R. Muratova,}

postgraduate student at the Department of Intenational Law, Moscow State Institute of International Relations (University) MFA Russia

76, pr. Vernadskogo, Moscow, Russian Federation, 119454

renata.muratova@hotmail.com

ORCID: 0000-0001-9441-3823
Информация об авторах

\section{Дмитрий Константинович Лабин,}

доктор юридических наук, профессор кафедры международного права, заведующий кафедрой публичного права, Московский государственный институт международных отношений (Университет) МИД России

119454, Российская Федерация, Москва, проспект Вернадского, д. 76

d.labin@inno.mgimo.ru

ORCID: 0000-0002-1493-4221

\section{Рената Равилевна Муратова,}

аспирант кафедры международного права, Московский государственный институт международных отношений (Университет) МИД России

119454, Российская Федерация, Москва, проспект Вернадского, д. 76

renata.muratova@hotmail.com

ORCID: 0000-0001-9441-3823 